\title{
Sandstone Reefs in Pernambuco Brazil, Macroalgae and Invertebrates Ecology Field Considerations
}

\author{
Mariana Alves de Guimaraens* \\ Instituto de Ciências Biológicas, Rua Arnóbio Marques, Brazil
}

Submission: December 16, 2020; Published: January 21, 2021

Corresponding author: Mariana Alves de Guimaraens, Universidade de Pernambuco, Instituto de Ciências Biológicas, Rua Arnóbio Marques, Recife, Brazil

\begin{abstract}
Environmental impacts are causing changes in community structure of different coastal ecosystems. The purpose of this review is to discuss such changes in sandstone reefs intertidal. Pollution and bio invasion are some of the impacts causing reef community changes with the dominance of competitors. Therefore, this shows the need of management strategies to protect reef community diversity and functional structure.
\end{abstract}

Keywords: Sandstone reefs; Macroalgae ecology; Invertebrate populations; Bio invasion

\section{Introduction}

Reefs are important structures that protect coastal areas and serve as fixation substrate for algae and invertebrates which are part of the food chain for the nekton and protection areas as well. In the Brazilian coast we have coral reefs as well as sandstone and algal based reefs. In Pernambuco state we have a $187 \mathrm{~km}$ costal extension where sandstone reefs are dominant as structures parallel to the coastline [1]. In this review I am going to focus in the intertidal zone of these reefs which are generally divided in back reef, front reef, and reef crest. Shark attacks are common in Pernambuco beaches which are related to the disturbance of mangrove and reef habitats which are nursery for these animals populations, therefore the study of underwater reefs is rare since diving is dangerous. However, there are artificial reefs in our coastline made of ships underwater that are important to increase fisheries and tourism industries. These reefs have been impacted by overfishing and pollution, as well as trampling and artificial burrowing with sand to increase beach extension. One extra of the causes for the shark attack problems is overfishing.

\section{Discussion}

The sewage disposal in estuaries has increased the algal growth and the phase shift in the reef intertidal communities changing them to algal dominated communities with domination of foliose and filamentous green algae, in certain circumstances such as the beginning of the dry season when there are less sediments and some nutrients in the water column [2]. Algal community diversity is affected by urbanization as well since areas with less edification have a greater community diversity with more rare species, such as calcified ones, than intertidal reefs in urbanized areas with dominant species such as Ulva that are related to eutrophization of urban areas. Bleaching is also increasing in reef areas in the intertidal zone's cnidarians such as Palythoa sp. have been shown to have impacted tissues which can be related to climatic changes as well as trampling in the intertidal reefs flat. Another impact to reef communities is bio invasion in our study area with bivalves such as Isognomon bicolor which compete with barnacles such as Tetraclita stalactifera and the mussel Brachidontes solisianus [3]. Corals such as Tubastrea have been recorded impacting subtidal areas of National Parks in the northeast Brazil competing with reef building corals such as Mussismilia brasiliensis. Experiments of succession have been made on the reef flat of Piedade Beach showing that barnacles such as Chthamalus are superior competitors than Brachidontes solisianus which can show resistance to desiccation and show that mussels beds can be seasonal and therefore affected by bio invasion [4]. As well as colonization of the shell which can avoid shell opening and nutrition. Fisat analyses showed that Isognomon 
bicolor has a greater simulated shell length and growth rate than Brachidontes solisianus thus being a superior competitor than the native mussel. However other impacts such as desiccation and trampling, as well as recruitment can prevent domination of the bio invasion.

\section{Conclusion}

To end the general aspects of the reef ecology in the Brazilian coast is important to notice that conservation and management measures should be applied to conserve the reefs. In addition, we have noticed the role of sea level rise in changing the zonation of macroalgae on the reef increasing the red algae dominance in the mesolitoral of the reef flat.

\section{References}

1. Simões IP, MA Guimaraens, MF Oliveira-Carvalho, J Valdevino, SMB Pereira (2009) Avaliacão florística e sucessão ecológica das macroalgas em recifes na praia de Piedade (PE). Neotropical Biology and Conservation 4: 49-56.

2. Guimaraens MA, Silva JAM, Falcão D (2011) Temporal variability in macroalgae recruitment and succession on sandstone reefs at Piedade Beach - PE, Brazil. Neotropical Biology and Conservation 6: 170-177.

3. Guimaraens MA, Dias V (2015) Temporal Variation of Population Structure of the Invasive Isognomon bicolor (Mollusca, Bivalvia), Brachidontes solisianus (Mollusca, Bivalvia) and Ulva spp. (Chlorophyta, Ulvales) Biomass, Pernambuco, Brazil. International Journal of Marine Science 43: 1-5.

4. Guimaraens MA, Luz B R A, Silva JF, Carneiro JPS (2011) Modeling the succession of barnacles and mussels on a sandstone reef in Pernambuco State, Brazil Hydrobiologia 658: 365-372.

Your next submission with Juniper Publishers will reach you the below assets

- Quality Editorial service

- Swift Peer Review

- Reprints availability

- E-prints Service

- Manuscript Podcast for convenient understanding

- Global attainment for your research

- Manuscript accessibility in different formats ( Pdf, E-pub, Full Text, Audio)

- Unceasing customer service

Track the below URL for one-step submission https://juniperpublishers.com/online-submission.php 